\title{
Peertechz
}

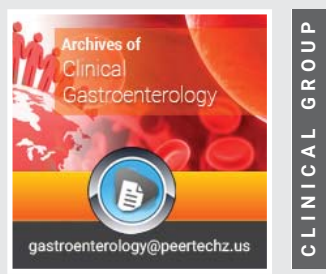

\section{Hyaline vascular-type Castleman's disease of the retroperitoneum}

\author{
Wei-Feng Huang', Yi Ding ${ }^{2}$ and Wei Liu ${ }^{3,4 *}$ \\ 'Department of Gastroenterology, The First Affiliated Hospital of Xiamen University, School of \\ Medicine, Xiamen University, Xiamen, China \\ ${ }^{2}$ Department of Pathology, The First Affiliated Hospital of Xiamen University, School of Medicine, \\ Xiamen University, Xiamen, China \\ ${ }^{3}$ Institute of Digestive Disease, China Three Gorges University, Yichang, China \\ ${ }^{4}$ Department of Gastroenterology, Yichang Central People's Hospital, Yichang, China
}

ISSN: $2455-2283$

DOI: https://dx.doi.org/10.17352/acg
Received: 25 January, 2022

Accepted: 03 February, 2022

Published: 04 February, 2022

*Corresponding author: Wei Liu, PhD, Institute of Digestive Disease, China Three Gorges University, 8 Daxue Road, Yichang 443000, China,

E-mail: liuwei@ctgu.edu.cn

ORCID: https://orcid.org/0000-0001-7118-815X

Copyright License: (c) 2022 Huang WF, et al. This is an open-access article distributed under the terms of the Creative Commons Attribution License, which permits unrestricted use, distribution, and $r$ eproduction in any medium, provided the original author and source are credited.

https://www.peertechzpublications.com

\section{Check for updates}

A 39-year-old man with newly diagnosed and well controlled hypertension was in his usual state of good health. He was diagnosed with a retroperitoneal tumor during a health check-up, which was suspicious of adrenal tumor by abdominal computed tomography. He denied any abdominal fullness, nausea, vomiting, changes in bowel habits, and body weight loss. On admission, his physical exam and laboratory investigations were both normal. Abdominal contrast-enhanced computed tomography showed a heterogeneous-solid, wellencapsulated and hypervascular mass in the retroperitoneal space, measuring $4.6 \times 3.0 \mathrm{~cm}$, between the right kidney and the right adrenal gland (Figure $1 \mathrm{~A}$ ). Primary retroperitoneal tumor was considered. Operative resection of the mass was performed and the resected specimen was an irregular mass, measuring $6.5 \times 5.0 \times 2.0 \mathrm{~cm}$ with the light brown cut surface macroscopically (Figure 1B). Microscopically, the specimen was characterized by hyperplasia of germinal centers, atrophy of lymph follicles, onion-skin appearance of the mantle zone around the germinal centers and lollipop appearance with sclerotic blood vessels radially penetrating atrophic germinal centers (Figure 1C). Furthermore, lymphomas were excluded based on the lesion staining infallibly immunoreactive for CD20, CD3, and CD21 by immunohistochemistry (Figure 1DF). Final diagnosis was hyaline-vascular type of localized Castleman's Disease on the basis of the above histopathologic examinations. Castleman's disease, related to human herpes virus type 8 , is a group of rare and heterogeneous disorders with characteristic lymph node histopathological abnormalities, which often occurs in the mediastinum and extrathoracic involvement [1]. However, retroperitoneal involvement is uncommon. The more common unicentric Castleman's disease usually has a better prognosis because of the localized solid mass. The presentations of unicentric Castleman's disease, mostly the hyaline-vascular types, usually present as an asymptomatic mass [2]. As described in this case, Castleman's
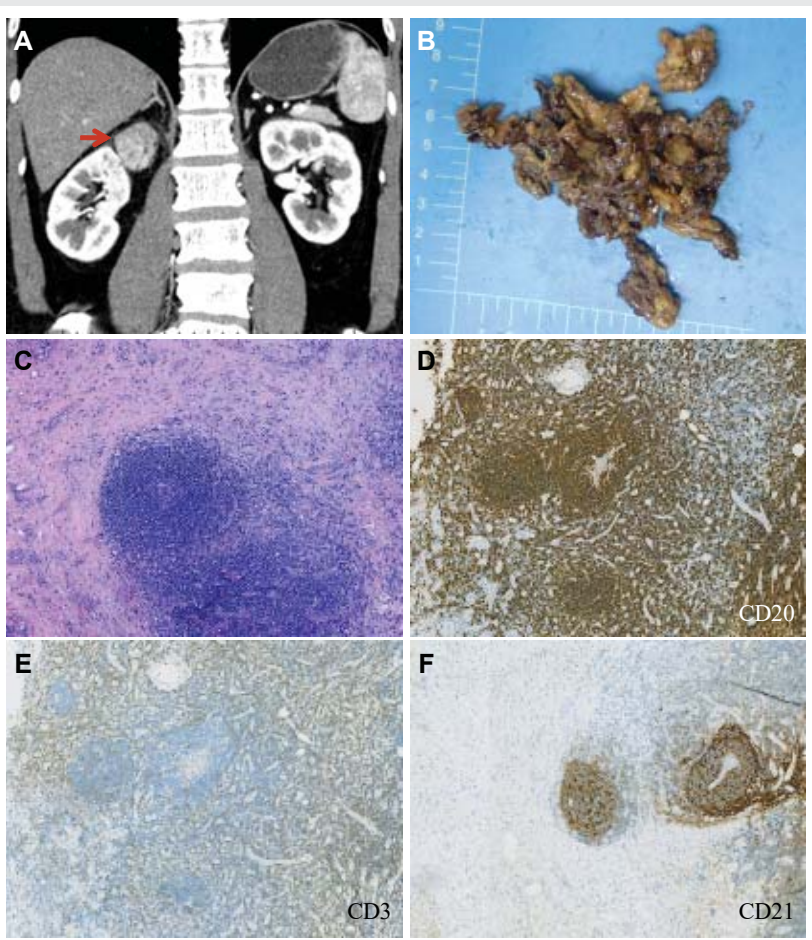

F

Figure 1: Hyaline Vascular-Type Castleman's Disease of the Retroperitoneum. (A). A heterogeneous-solid mass in the retroperitoneal space defined by computed tomography. (B). Operative resection of the mass. (C). Hematoxylin and eosin staining of the lesion. (D-F). Immunohistochemical analysis positive for CD20, CD3, and CD21 in neoplastic cells. 
disease with an asymptomatic and retroperitoneal tumor in young man is rare. Early diagnosis and surgical resection of an unusual retroperitoneal tumor are significantly important to prevent tumor aggravation although Castleman's disease with a localized form is a kind of benign tumor $[2,3]$. As a diagnostic and curative therapeutic method, complete surgical resection is the preferred therapy for the unicentric form [1,4]. After surgery, no recurrence and episodes were noted for our patient in the next several years.

\section{Acknowledgement}

\section{Funding}

This work was supported by National Natural Science Foundation of China (31600134) and Medical and Health Guiding Project of Xiamen (3502Z20214ZD1028).

\section{Ethical statement}

The authors are accountable for all aspects of the work in ensuring that questions related to the accuracy or integrity of any part of the work are appropriately investigated and resolved. Written informed consent was obtained from the patient for publication of this "GI Image".

\section{Author's contributions}

Collection of data and writing: Wei-Feng Huang.

Pathology analysis and interpretation: Yi Ding.

Final approval of the manuscript: Wei Liu.

\section{References}

1. van Rhee F, Oksenhendler E, Srkalovic G, Voorhees P, Lim M, et al. (2020) International evidence-based consensus diagnostic and treatment guidelines for unicentric Castleman disease. Blood Adv 4: 6039-6050. Link: https://bit.ly/3L8SqPe

2. Nien HC, Lien HC, Chen $\mathrm{CH}$ (2010) An unusual retroperitoneal tumor in a young woman. Gastroenterology 139: 1836. Link: https://bit.ly/3rwHkfv

3. Zanchi C, Paloni G, Marchetti F (2012) Recurrent fever and fitful abdominal pain in a child. Gastroenterology 143: e11-12. Link: https://bit.ly/3okuq1S

4. Wang W, Dong D, Wen J, Li H (2021) A 10-year observational single-center study of retroperitoneal unicentric Castleman disease. Medicine (Baltimore) 100: e25088. Link: https://bit.ly/3AROyxs
Discover a bigger Impact and Visibility of your article publication with

\section{Peertechz Publications}

\section{Highlights}

* Signatory publisher of ORCID

* Signatory Publisher of DORA (San Francisco Declaration on Research Assessment)

* Articles archived in worlds' renowned service providers such as Portico, CNKI, AGRIS, TDNet, Base (Bielefeld University Library), CrossRef, Scilit, J-Gate etc.

* Journals indexed in ICMJE, SHERPA/ROMEO, Google Scholar etc.

- OAI-PMH (Open Archives Initiative Protocol for Metadata Harvesting)

* Dedicated Editorial Board for every journa

* Accurate and rapid peer-review process

* Increased citations of published articles through promotions

* Reduced timeline for article publication

Submit your articles and experience a new surge in publication services (https://www.peertechz.com/submission). 